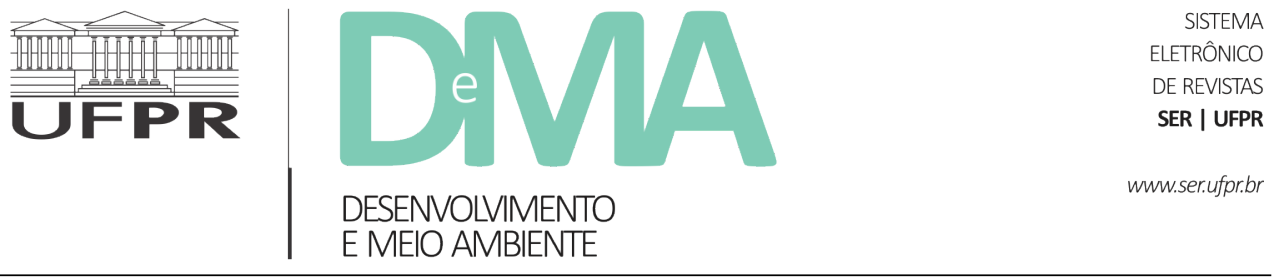

\title{
The regional market for non-timber forest products
}

\section{O mercado regional para produtos florestais não madeireiros}

\author{
Matleena VUOLA ${ }^{1}$, Simone C. BAUCH², Erin O. SILLS ${ }^{3 *}$ \\ ${ }^{1}$ Former graduate student, North Caroline State University, Raleigh, North Carolina, U.S.A. \\ ${ }^{2}$ Global Canopy Programme, Oxford, United Kingdom. \\ ${ }^{3}$ North Carolina State University, Raleigh, North Carolina, U.S.A. \\ *E-mail de contato: sills@ncsu.edu
}

Article received in April 9, 2018, final version accepted in August 16, 2018.

ABSTRACT: The fate of tropical forests is shaped by their perceived value, which in turn depends on awareness of their benefits. Regional markets for non-timber forest products (NTFPs) could both help rural people generate income from forests and raise urban awareness of forest benefits. We assess the urban market for NTFPs in Belém do Pará, the largest metropolitan area in the Brazilian Amazon, through a survey of consumers in 2006 - 2009. We segmented the urban consumer market in order to explore patterns in consumption and knowledge about NTFPs. We find that the market segments that consume the greatest number of NTFPs were characterized by relatively higher income and education as well as more recent migration to Belém. This suggests that demand for non-timber forest products does not fade with improved socioeconomic status. However, environmental education is needed to convert this demand into recognition of the benefits provided by forests, as many consumers are not aware that the products they consume come from the forest. In the two largest consumer segments, most consumers could not spontaneously list any forest product they consume, even though when a list of NTFPs was presented, many $(>75 \%)$ indicated that they did consume the two most popular forest products: açaí palm fruit (Euterpe oleraceae) and Brazil nuts (Bertholletia excelsa). Consumers in these largest segments have lower incomes, are more likely to have been born in Belém and are less likely to have completed postsecondary education. In addition to not recognizing that they consume forest products, many of these consumers had no direct experience of the forest: less than half of the survey respondents in these segments reported that they had ever visited the forest, despite living in a city located in the midst of the largest tropical forest in the world.

Keywords: non-timber forest products; Brazilian Amazon; regional markets; market segmentation. 
O destino das florestas tropicais é definido pelo seu valor percebido. Mercados regionais para produtos florestais não-madeireiros (PFNM) poderiam ajudar a população rural a gerar renda das florestas e aumentar a percepção urbana dos benefícios gerados pela floresta. Avaliamos o mercado de PFNM em Belém do Pará, a maior área metropolitana da Amazônia brasileira, através de questionários aplicados a consumidores entre 2006 e 2009. Segmentamos o mercado consumidor urbano para explorar padrões relacionados àconsumo e conhecimento de PFNM. Os resultados mostram que os segmentos de mercado que consomem o maior número de PFNM são caracterizados por renda e escolaridade relativamente mais altas e migração mais recente para Belém. Isto sugere que a demanda por PFNM não irá desaparecer com a melhoria do status socioeconômico. Porém, educação ambiental será necessária para converter esta demanda para que esta apoie a conservação de florestas, já que muitos consumidores não sabem que os produtos consumidos vem da floresta. Nos dois maiores segmentos de mercado, a maioria dos consumidores não soube listar espontaneamente nenhum PFNM que consumia, apesar de que, quando apresentados com uma lista de PFNM, muitos ( $>75 \%)$ indicaram que consumiam os produtos florestais mais populares: açaí e castanha do Pará. Consumidores nestes maiores segmentos tem renda mais baixa, com maior probabilidade de terem nascido em Belém e menor chance de terem completado educação superior. Além de faltar conhecimento sobre produtos florestais, estes consumidores também faltam exposição à floresta: menos da metade dos consumidores nestes segmentos reportaram que já visitaram a floresta, apesar de morarem em uma cidade localizada no interior da maior floresta tropical do mundo.

Palavras-chave: produtos florestais não madeireiros; Amazônia brasileira; mercados regionais; segmentação de mercado.

\section{Introduction}

Part of the legacy of rubber tapper Chico Mendes was the establishment of "extractive reserves" for forest communities whose people depend for their livelihoods on the gathering, use, and marketing of diverse non-timber forest products (NTFPs). While export of NTFPs has been seen as a key strategy for economic development of the reserves, regional markets also hold potential because local consumers are easier to reach and often have a cultural affinity for NTFPs (Shackleton et al., 2007). Further, consumption of NTFPs could increase awareness of the provisioning value of forests, thereby helping to create a local urban constituency for extractive reserves. This paper therefore focuses on the consumers of NTFPs in a regional market center in the Amazon.
The metropolitan area of Belém in the eastern Brazilian Amazon is a quintessential example of a vibrant regional market for NTFPs, perhaps especially well known for its medicinal products (Shanley \& Luz, 2003). However, as is the case with many tropical cities, Belém's population and economy are growing rapidly, and this could change the regional market for NTFPs, e.g. due to the lack of familiarity with NTFPs among new arrivals, the "nutrition transition" from diverse locally produced foods to a simplified diet of processed foods (Popkin, 2004), and the growing market share of supermarkets (Asfaw, 2008). These arguments confirm the importance of understanding the regional market, including how it is segmented into consumer groups with different purchasing behaviour and different understanding of NTFPs. We present results of a market segmentation analysis based on a 2006 - 2009 survey of consumers in Belém. 


\section{Methods}

\subsection{Study Area and time period}

Belém is the capital of the state of Pará in the North of Brazil. The city lies on the Pará River, in the Amazon River delta. In 2010, the population of Belém was about 1.39 million people, and the average monthly per capita household income was BRL $\$ 697$ (USD \$396 US dollars, at exchange rate of 07/14/2010 as reported by oanda.com), only about a third higher than the national monthly minimum wage per person of R $\$ 510$ (IBGE, 2012). Over the past 50 years, both the population and the economy of Belém have grown rapidly, reflecting rapid development (and deforestation) in the Amazon as a whole. However, during the time period of our study, from 2006 to 2009, both deforestation in the Amazon and population growth in Belém had slowed down relative to previous years.

In Belém, NTFPs, along with agricultural products, are traditionally sold in open-air markets or "fairs" where vendors have permanent stalls. These products are typically brought by boat to the city's three major ports and then distributed to open-air markets throughout the city (Figure 1). The largest and best known of these markets is called Ver-o-Peso, located immediately next to a port in downtown Belém, which had more than 75 vendors selling forest products in 2006. The other markets varied enormously in terms of the availability of forest products: in some, only a couple of vendors sold NTFPs, while six markets had more than 30 vendors each selling NTFPs. NTFPs are also sold by street vendors, natural pharmacies, juice and ice cream stores, small grocery and corner stores, and regional or national supermarket chains.

\subsection{Data collection}

From 2006 to 2009, Imazon (Instituto do Homem e Meio Ambiente da Amazônia, or Amazon Institute of People and Environment) conducted an intercept survey of shoppers in Belém, inquiring about their consumption and purchases of NTFPs, as part of a larger project called "Bridging the divide: Enhancing Forest Tenure, Management and Marketing in the Brazilian Amazon" (Amaral et al. 2008). The survey was conducted in three types of locations:

1. the Ver-o-Peso;

2. 9 neighborhood open-air markets, selected as a random stratified sample of markets with different numbers of vendors selling forest products;

3. 6 supermarkets, selected as a random stratified sample of supermarkets in the three largest supermarket chains operating in Belém.

During the main harvest season for most perishable NTFPs (February to April), interviews were conducted face-to-face by teams of interviewers - including mostly university students - who were trained and supervised by Imazon researchers. The survey instrument had fewer than 30 questions, ensuring that interviews could be completed while standing in the check-out line or walking through the market. The first section asked about consumption of NTFPs. Because respondents were unlikely to be familiar with the term "non-timber forest 


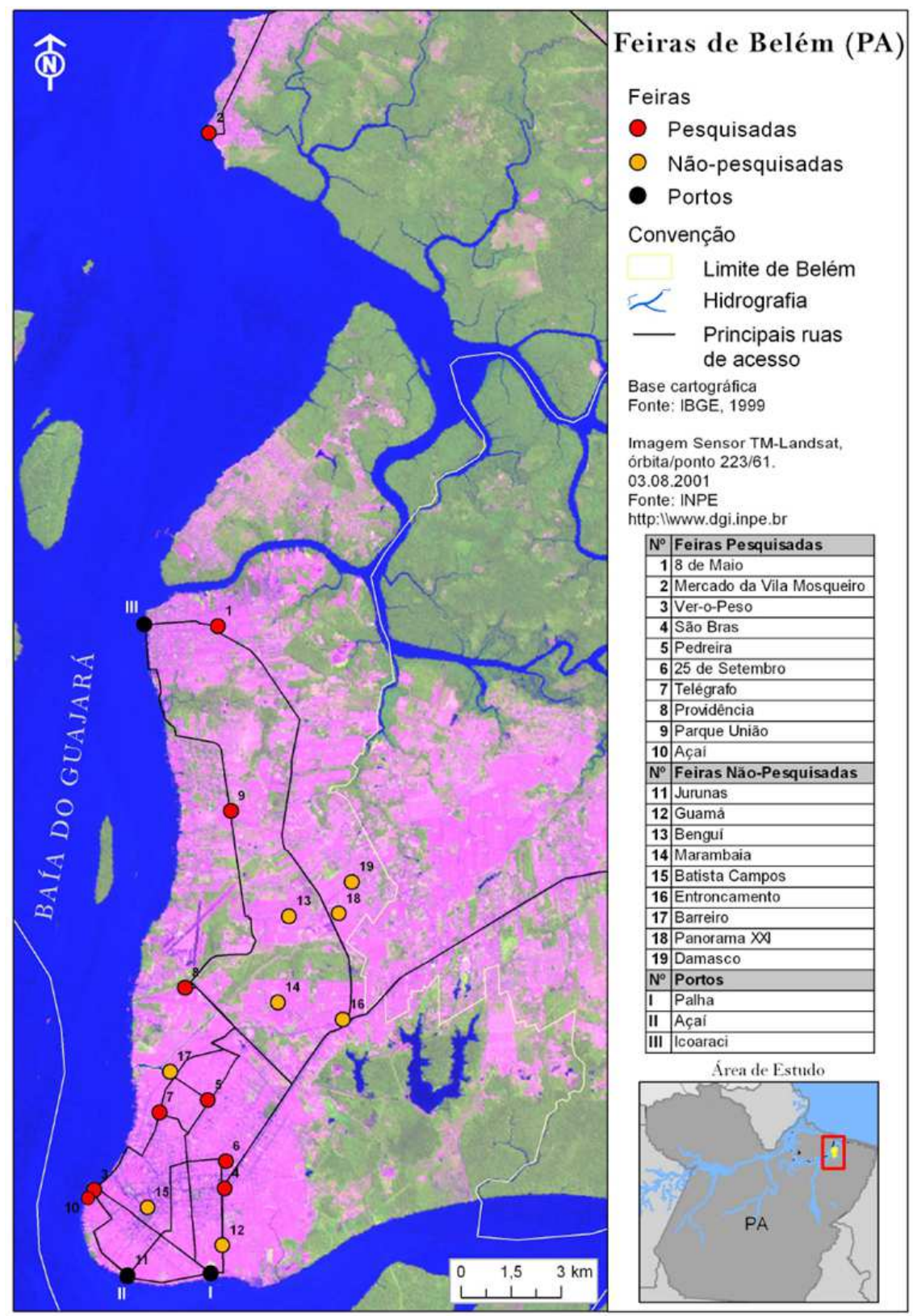

FIGURE 1 - Open-air markets in Belém. 
product," the interview began with an open-ended question eliciting a list of up to eight products from the forest that the respondent consumed. These were later categorized as edible, medicinal, animal or other NTFPs, or non-forest products (i.e. agricultural products). This was followed by questions about whether the respondent consumed each of seven focal NTFPs that had been previously identified as the most popular: açaí palm fruit (Euterpe oleraceae), medicinal oils (andiroba, Carapa Guianensis and copaiba, Copaifera sp), fruits (piquiá, Caryocar villosum, uxi, Endopleura uchi, and bacuri, Platonia insignis), and Brazil nut (Bertholletia excelsa). After asking about the seven focal products, the interviewers asked respondents to state the product on which they spend the most money. The second section of the questionnaire asked more detailed questions about one of the focal products, meaning that there were seven different versions of the questionnaire randomly distributed across respondents (Bridging the Divide, 2013). The third section inquired about socio-economic characteristics. Income was elicited by listing seven categories of monthly income and asking the respondents to indicate which characterized their households. Interviewers reported that most of the people they approached were willing to answer all questions.

In total, 2,636 people were interviewed, including 715 in 2006, 653 in 2007, 217 in 2008, and 853 in 2009. The distribution across types of interview locations is shown in Table 1, along with descriptive statistics for respondents interviewed in each type of location. People interviewed in supermarkets have higher education and income levels, but it is important to note that most respondents shop in multiple locations, and in fact, respondents interviewed in one type of location may typically shop for NTFPs in another type of location. Thus, for purposes of market segmentation, we pool all responses across years and interview locations. This provides a robust picture of the market in the late 2000s, not affected by idiosyncratic year-to-year changes or the particularities of consumers who shop in any of the locations.

\subsection{Data analysis}

In order to identify distinct segments of the market for NTFPs in Belém, we employ "behavior-based" or "habit-based" segmentation to identify groups of shoppers that are relatively homogenous in their NTFP consumption and purchasing behavior. This approach is used in marketing and advertising to identify retail customer prototypes, which are then described based on their socio-demographic characteristics (Rossiter \& Percy, 1987). Rather than prototyping the customers of a particular retail establishment, we seek to identify groups of consumers with similar behavior and knowledge of NTFPs.

To analyze our data, we used two-step cluster analysis in SPSS (SPSS, 2001), as is generally recommended for clustering large datasets including different types of variables (e.g. categorical and continuous) (Garson, 2012). We created five variables based on the open-ended responses about consumption and spending on forest products:

EDIBLE $=$ the number of edible NTFPs the respondent reported in the question "Which forest products do you consume?" This category includes most of the focal products (açai, bacuri, Brazil nut, piquiá, and uxi). 
TABLE 1 - Socio-demographics by interview location (2006 - 2009).

\begin{tabular}{|c|c|c|c|}
\hline Variable & Neighborhood markets & Ver-o-peso & Supermarkets \\
\hline Percent female & 57.1 & 48 & 66.1 \\
\hline Mean age & 40.3 & 43 & 38.8 \\
\hline Percent with tertiary (postsecondary) education* & 19.1 & 20.2 & 38.6 \\
\hline Mean family size & 4.6 & 4.6 & 4.4 \\
\hline $\begin{array}{l}\text { Mean family income } \\
\text { (BRL\$/month)** }\end{array}$ & 1,499 & 1,423 & 2,001 \\
\hline $\begin{array}{l}\text { Median family income } \\
(\text { BRL } \$ \text { month)** }\end{array}$ & 1,250 & 750 & 1,250 \\
\hline
\end{tabular}

* Detailed information on educational attainment was not collected in 2006, so education statistics exclude that year.

** Mean and median calculated by assuming the mid-point of each income category as the income of respondents who selected that category.

MEDICINAL $=$ the number of medicinal NTFPs the respondent reported in the question "Which forest products do you consume?" This category includes the remaining two focal products (andiroba and copaiba), as well as other medicinal plants like barbatimão (Stryphnodendron adstringens).

ANIMAL $=$ the number of animal NTFPs the respondent reported in the question "Which forest products do you consume?" This includes both fish and game meat.

OTHERPROD $=$ the number of NTFPs not in the previously mentioned categories (edible/ medicinal/animal) that the respondent reported in the question "Which forest products do you use?" Examples include vines and other crafting materials such as miriti.

SPENDMOST $=$ the NTFP category (edible/ medicinal/animal/other) on which the respondent spends the most.
The counts for ANIMAL and OTHERPROD were very small or zero for many respondents and, perhaps for that reason, they had little influence on the clusters. We therefore dropped them from the final cluster analysis. In this final analysis, we treated EDIBLE and MEDICINAL as ordinal variables, because they represent the number of forest products that easily came to the minds of survey respondents and thus reflect their level of awareness about NTFPs. This interpretation is consistent with the fact that many respondents reported that they did consume focal NTFPs when prompted, even if they had not listed them in response to the first open-ended question.

After identifying the clusters, we characterize them based on the three variables used in the cluster analysis, validate them based on responses to questions about the focal NTFPs, and profile each cluster or segment based on socio-demographic characteristics including age, sex, education, income, and origin, as well as preferred place to shop 
for NTFPs. In addition, we assess each segment's knowledge of NTFPs by examining whether they actually listed forest products in response to the open-ended survey questions.

\section{Results and discussion}

Across the four years of the survey, respondents indicated that they consumed over 250 different products. As shown in Table 2, the ten most frequently mentioned products across the years include six NTFPs: açaí, bacuri, cupuaçu, pupunha, uxi and Brazil nut. These six are all edibles that grow on trees. Most of the other products in the top ten for each year are fruits that are produced in orchards or plantations and are not native to the Amazon.

Through two-step cluster analysis, we identified five market segments (Figure 2) with a reasonable ratio (1.85) of the largest (650 consumers) to smallest (352 consumers) segments and a silhouette measure of 0.6 , indicating a good cluster solution (Mooi \& Sarstedt, 2011). Of the three variables used in the final analysis, SPENDMOST and EDIBLE were the most important predictors. Table 3 describes each segment in terms of the three variables. The segments are labeled based on both those descriptions and consumption of the focal products, as shown in Figure 3.

The five market segments can be described as follows:

1. Self-perceived as non-consumers:

The largest market segment identified by the cluster analysis (almost 25\% of respondents) includes consumers who do not report buying any NTFPs. Specifically, they report consuming no edible NTFPs and no medicinal NTFPs, and when asked which product they spend the most on, they mentioned a product other than a NTFP. We label them as "self-perceived" non-consumers, because many of them nevertheless said that they consumed

TABLE 2 - Ten most frequently mentioned products by consumers interviewed in each year.

\begin{tabular}{ccccc}
\hline \multirow{2}{*}{ Rank } & \multicolumn{2}{c}{ Products } & 2009 \\
\hline 1 & cupuaçu & cupuaçu & banana & banana \\
2 & açaí & banana & cupuaçu & cupuaçu \\
3 & banana & bacuri & bacuri & açaí \\
4 & bacuri & açaí & pupunha & orange \\
5 & orange & melon & orange & melon \\
6 & mango & pupunha & Brazil nut & apple \\
7 & apple & orange & açaí & pupunha \\
8 & pupunha & uxi & melon & bacuri \\
9 & avocado & Brazil nut & uxi & mango \\
10 & Brazil nut & pineapple & avocado & avocado \\
\hline
\end{tabular}




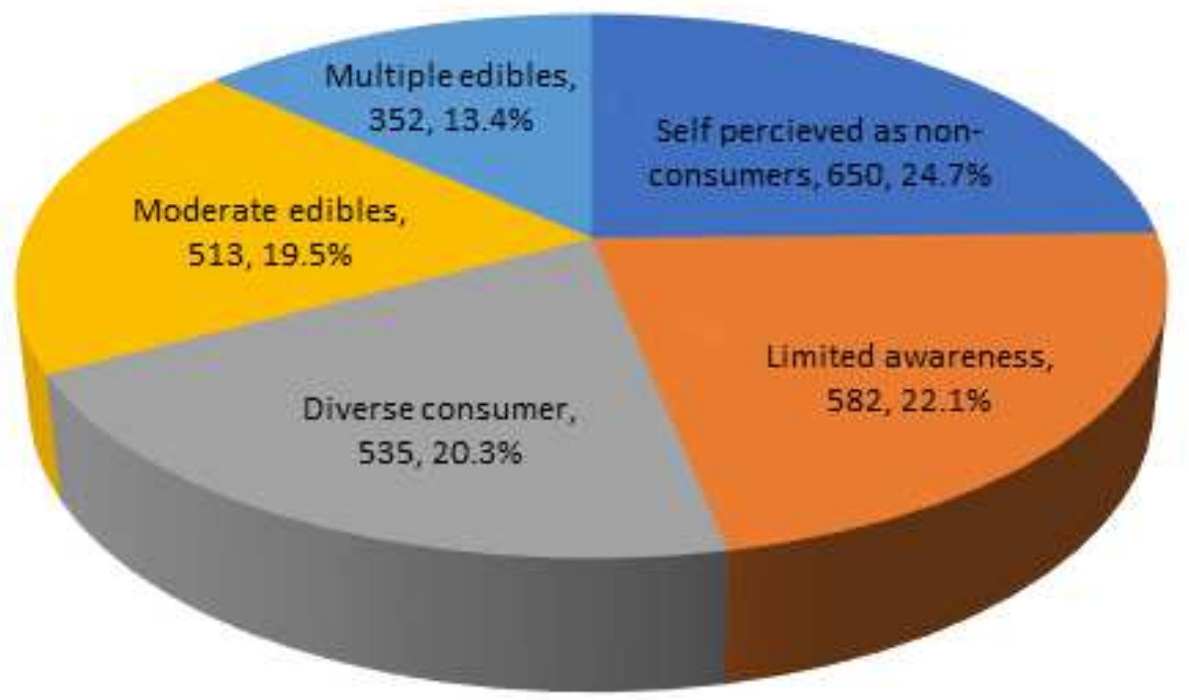

Total samplesize: 2635

FIGURE 2 - Forest product market segments based on two-step cluster analysis.

the focal NTFPs, in response to specific questions about those products.

2. Limited awareness:

The consumers in this segment do not list any NTFPs in response to the open-ended question about which forest products they consume. However, $100 \%$ of the consumers in this segment report spending the most on edible NTFP, most likely because the questions about the focal products reminded them about forest products that they do consume. Thus, the consumers in this segment are not very aware of NTFPs, but they do consume edible NTFPs.
3. Diverse consumer:

This is the only segment that reports consuming medicinal NTFPs as well as edible NTFPs. Respondents in this segment are most likely to report an agricultural product as the forest product on which they spend the most. Thus, these consumers both assume that a wide range of products are from the forest and consume a variety of forest products.

\section{Moderate edibles:}

Over half $(53 \%)$ of the respondents in this segment report consuming two edible NTFPs, and most of the rest report consuming one edible NTFP (with a very few reporting animal NTFPs as well). 
Everyone in this segment spends the most on an edible NTFP. Thus, this segment is characterized by moderate variety of NTFP consumption.

\section{Multiple edibles:}

The consumers in this segment consume several different edible NTFPs, with most of them (59\%) reporting three products, but nearly a third (29\%) consuming four products. This is the smallest segment, including just $13.5 \%$ of respondents.

In order to validate this market segmentation, we also consider responses to the questions about consumption of each of the focal products (Figure 3). Over half of all segments consume açaí, andiroba, bacuri, Brazil nut, and copaiba. Thus, even though these products did not come to mind as "forest products," they are widely consumed. As expected, the largest fraction of consumers in the diverse consumer segment consume the two medicinal oils (andiroba and copaiba) while the largest fraction of consumers in the multiple edibles segment consume açaí, bacuri, and Brazil nut. There is more variation in the probability of consuming piquiá and uxi, with low rates among self-perceived non-consumers and limited awareness consumers, moderate rates among moderate edibles consumers, and the highest rates in the multiple edibles segment. These patterns confirm our market segmentation.

Table 4 describes the socio-demographic characteristics of each segment. Given the surprisingly high percentage of respondents that listed non-forest products as NTFPs, we also add a variable indicating whether respondents have ever been in the forest.

The segment that perceives themselves as non-consumers has the highest percentage of female respondents (65.6\%), the lowest income, the lowest percentage of people who have finished higher education (17.4\%), and the lowest percentage of

TABLE 3 - Segment description.

\begin{tabular}{|c|c|c|c|c|c|}
\hline & $\begin{array}{l}\text { Self-perceived } \\
\text { as non- } \\
\text { consumer }\end{array}$ & $\begin{array}{c}\text { Limited } \\
\text { awareness }\end{array}$ & $\begin{array}{l}\text { Diverse } \\
\text { consumer }\end{array}$ & $\begin{array}{c}\text { Moderate } \\
\text { edibles }\end{array}$ & $\begin{array}{c}\text { Multiple } \\
\text { edibles }\end{array}$ \\
\hline Size & $24.7 \%(\mathrm{n}=650)$ & $22.1 \%(\mathrm{n}=582)$ & $20.3 \%(\mathrm{n}=535)$ & $\begin{array}{c}19.5 \% \\
(\mathrm{n}=513)\end{array}$ & $\begin{array}{c}13.4 \% \\
(\mathrm{n}=352)\end{array}$ \\
\hline $\begin{array}{l}\text { Modal number of edible NTFPs } \\
\text { consumed (percent of segment } \\
\text { reporting that number) }\end{array}$ & $0(100 \%)$ & $0(100 \%)$ & $1(38.5 \%)$ & $2(52.4 \%)$ & $3(58.5 \%)$ \\
\hline $\begin{array}{l}\text { Percent who consume medicinal } \\
\text { NTFPs }\end{array}$ & $0 \%$ & $0 \%$ & $30.3 \%$ & $0 \%$ & $0 \%$ \\
\hline $\begin{array}{l}\text { Category that most commonly } \\
\text { report spending the most on }\end{array}$ & $\begin{array}{l}\text { Non-NTFP } \\
(100 \%)\end{array}$ & Edible $(100 \%)$ & $\begin{array}{l}\text { Non-NTFP } \\
\quad(63 \%)\end{array}$ & Edible $(100 \%)$ & Edible $(100 \%)$ \\
\hline
\end{tabular}




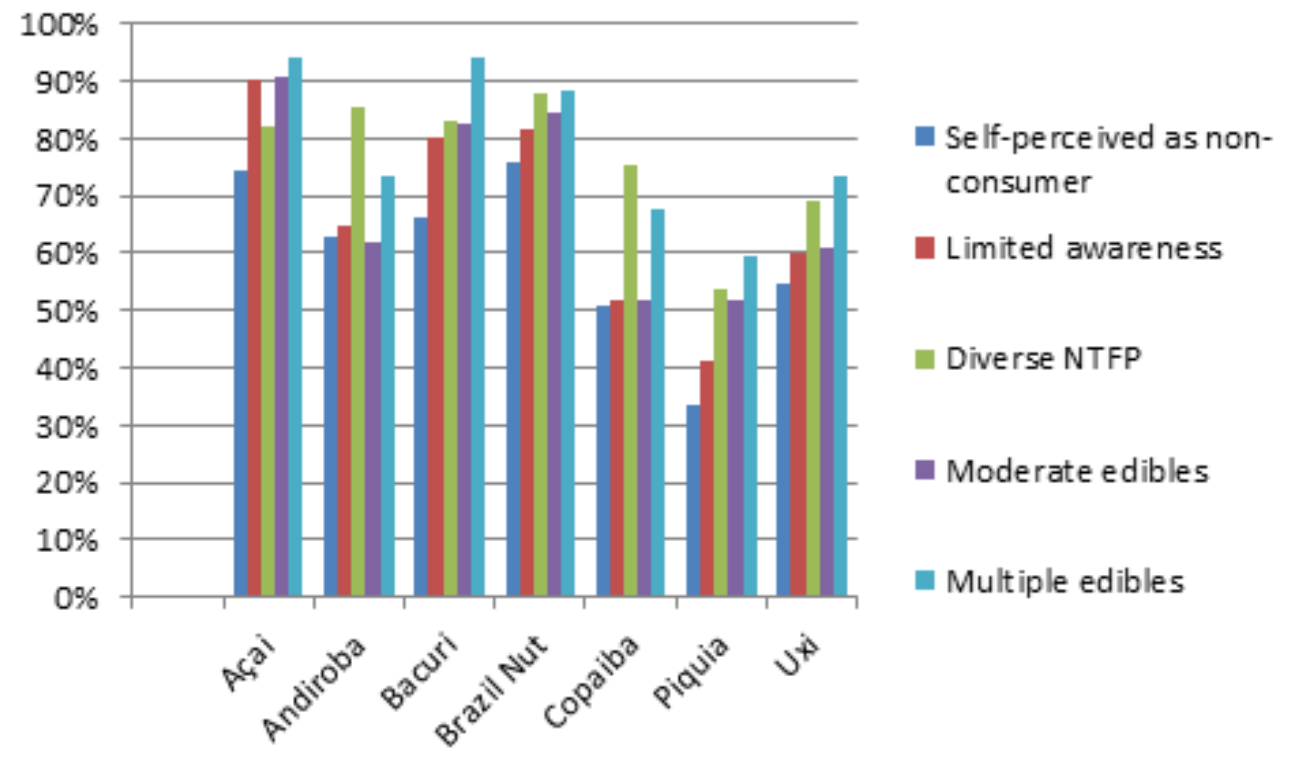

FIGURE 3 - Percent of consumers in each segment that consume the focal NTFPs.

people who have ever entered the forest (49.2\%). The limited awareness segment has similar characteristics, including the highest proportion of consumers $(65.1 \%)$ originally from Belém.
Thus, the two largest segments $(25 \%$ perceived non-consumers and $22 \%$ limited awareness) are more likely to have been born in Belém, less likely to have advanced education, and have lower inco-

Table 4 - Socio-demographic characteristics of segments.

\begin{tabular}{|c|c|c|c|c|c|c|c|c|c|}
\hline Variable & $\begin{array}{l}\text { Self-perceived } \\
\text { as non- } \\
\text { consumer }\end{array}$ & \multicolumn{2}{|c|}{$\begin{array}{c}\text { Limited } \\
\text { awareness }\end{array}$} & \multicolumn{2}{|c|}{$\begin{array}{l}\text { Diverse } \\
\text { consumer }\end{array}$} & \multicolumn{2}{|c|}{$\begin{array}{c}\text { Moderate } \\
\text { edibles }\end{array}$} & \multicolumn{2}{|c|}{ Multiple edibles } \\
\hline $\begin{array}{l}\text { forest? (yes) } \\
\text { fored the }\end{array}$ & $49.2 \% \quad(n=262)$ & $59.8 \%$ & $(n=337)$ & $72.1 \%$ & $(n=199)$ & $66.2 \%$ & $(n=210)$ & $78.7 \%$ & $(n=166)$ \\
\hline Gender (female) & $65.6 \% \quad(n=420)$ & $57.3 \%$ & $(n=330)$ & $61.9 \%$ & $(n=330)$ & $52.0 \%$ & $(n=266)$ & $53.1 \%$ & $(n=187)$ \\
\hline $\begin{array}{l}\text { Place of birth } \\
\text { (Belém) }\end{array}$ & $59.7 \% \quad(n=383)$ & $65.1 \%$ & $(n=375)$ & $51.6 \%$ & $(n=275)$ & $58.8 \%$ & $(n=301)$ & $51.3 \%$ & $(\mathrm{n}=180)$ \\
\hline $\begin{array}{l}\text { Tertiary } \\
\text { education (yes) }\end{array}$ & $17.4 \% \quad(n=82)$ & $23.7 \%$ & $(n=124)$ & $29.4 \%$ & $(n=65)$ & $29.5 \%$ & $(\mathrm{n}=86)$ & $40.4 \%$ & $(n=65)$ \\
\hline $\begin{array}{l}\text { Median income } \\
\text { (BRL) }\end{array}$ & 1353 & 1570 & & 1701 & & 1852 & & 2078 & \\
\hline
\end{tabular}


mes. They are also less likely to have ever been in the forest, suggesting that urban consumers' direct experience with the forest may be through educational or recreational activities that are less accessible to those with lower socio-economic status. Most of the respondents in these two segments do consume at least the two most popular NTFPs, with over $75 \%$ saying that they consume açaí and Brazil nut, but they evidently do not think of them as forest products. This suggests that these two segments likely contribute the least to the market value of forests and are the least aware of the provisioning value of forests, which may be related to both their low levels of education and income and their limited familiarity with forests.

The diverse consumer and multiple edibles segments have in common the smallest proportions of people native to Belém $(<52 \%)$ and the largest proportions of people who have visited the forest $(>72 \%)$. The multiple edibles segment has the highest education and income levels. The diverse consumer and moderate edible segments have similar income and education levels, but are differentiated by the higher proportion of people from Belém and smaller proportion of people who have been in the forest in the moderate edibles segment.

Consumer segments may also be differentiated by where they shop, but as illustrated by Figure 4, the distribution of respondents across segments in this study is not related to the distribution of where they typically buy NTFPs. In all segments, the greatest proportion shop in the open-air neighbourhood markets. Supermarkets are generally gaining market share in Belém, both because of their competitive prices and because of their convenience, i.e. they are open for longer hours and on all days of the week, and they are also located in all parts of the city. It is notable that a relatively large proportion of the people who shop for NTFPs in supermarkets are in the segment with limited awareness of NTFPs (29.6\% vs. $19.8 \%$ of all other shoppers) and a relatively small percentage are diverse consumers ( $15.3 \%$ vs $23.4 \%$ of all other shoppers). On average, people who typically buy NTFPs in supermarkets have higher purchasing power: BRL2243.4 average income, as compared to BRL1657.3 average income for all other consumers.

\subsection{Limitations and recommendations for further research}

While this study provides a unique snapshot of the consumer market for forest products in one of the major urban centers within the Amazon, some aspects of the survey design limit what we can learn from the data. In order to obtain a representative sample of consumers, the survey was conducted through intercept interviews in markets and grocery stores. This placed a strict limitation on the length of the interview, leading to the split sample design with most questions about one focal product. This generated important information for market participants, but it limits what we can learn about the market for NTFPs in general. We rely primarily on the opening question about "which forest products you consume", but we recognize that the answers reflect both knowledge and consumption of those products. The survey generates information specifically on consumption only of the focal products.

Imazon discontinued the survey of consumers after four years, when project funding ended. In the ten years since the last wave of the survey, much could have changed in the market. This presents an 


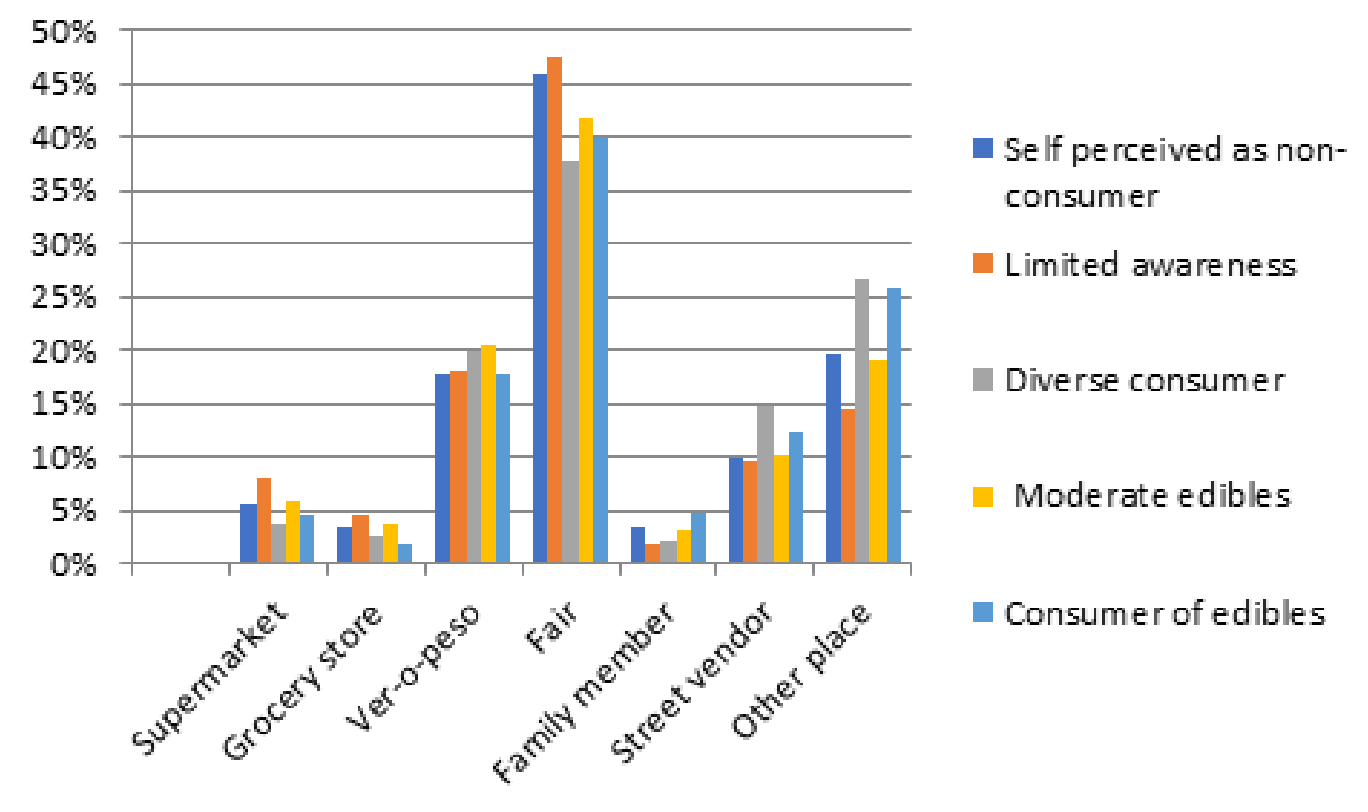

FIGURE 4 - Percent of consumers in each segment that typically buy NTFPs from each source.

important opportunity for additional research using this survey as a baseline in order to assess how the market for NTFPs is evolving.

By focusing on regional consumers, our study helps fill a lacuna in the literature on NTFPs. However, it is important to interpret our findings in light of information on the supply of NTFPs. In particular, harvest of NTFPs can be but it is not necessarily sustainable (Ticktin, 2004; Shanley et al., 2011). For example, Almeida et al. (2009) found that marketed quantities fell for 22 out of 28 NTFPs in the Amazon that they studied during the time period from 1982 to 2005 . They suggest that this was due to increasing harvesting costs and/or traditional harvesters exiting the business, which in turn may have been caused by deforestation, forest fires and unsustainable harvesting of some of the products.

\section{Conclusion}

In the late 2000s, the residents of Belém consumed a wide variety of NTFPs, with fruits being the most common. The seven focal NTFPs were popular during the study period, with over $95 \%$ of respondents reporting consumption of at least one of these products.

Urban residents who consume NTFPs were not necessarily aware that they were native forest products: according to the cluster analysis, about half 
of consumers fell into two market segments with very limited awareness of NTFPs. These segments were comprised of people with less education and lower income, and more people who were natives of Belém. Their lack of awareness of NTFPs likely means that they did not recognize the value of the native Amazon forest for provisioning services, even though they did actually buy forest products that generate income for the producers who harvest the products.

While awareness of forest products may not automatically lead to support for forest conservation, recognition of the benefits provided by the forest is an important first step. The consumption of NTFPs in Belém presents an opportunity for environmental educators to raise awareness of forest provisioning services. This could be incorporated into efforts to preserve the cultural heritage of the city (e.g. the Ver-o-Peso market as a showcase of regional products) and to promote improved nutrition and food security (cf. Johns \& Sthapit, 2004). For example, some school districts have incorporated regional products, including NTFPs, into school lunch programs, which are likely to serve many of the families in the market segments with limited awareness of NTFPs.

The market segments that have greater awareness and consume a greater variety of NTFPs are characterized by higher income and education levels and more recent migration to Belém. Over two thirds of the consumers in these three segments had visited the forest. They generally consume multiple NTFPs, including all of the focal NTFPs and a variety of others. If these segments grow, that could imply increased demand for forest products and recognition of the provisioning value of the forest.

\section{Acknowledgments}

Imazon implemented the market survey with funding from the European Commission. We are grateful to the many interns who interviewed consumers, including Ana Carolina Casemiro Vieira, Helga Yamaki, Laize Sampaio Silva, Mariana Vedoveto, Patrícia da Silva, Rogério Loturco Orsi, and Shana Sampaio Sieber.

\section{References}

Almeida, A. N.; Bittencourt, A. M.; Santos, A. J.; Eisfeld, C.; Souza, V. S. Production and price evolution of the main extractive non-timber forest products in Brazil. /Evolução da produção e preço dos principais produtos florestais não madeireiros extrativos do brasil. Cerne, 15(3), 282-287, 2009.

Amaral, P.; Amaral, M.; Bauch, S.; Ehringhaus, C.; Sills, E.; Vidal, E.; Ramos, C. A. Bridging the Divide: A Consortium Approach to the Multi-Scale and Multi-Dimensional Challenges of Sustainable Community Forest Management in the Brazilian Amazon. 2008. Available at: https://conference. ifas.ufl.edu/tropics/abstract_PDFs/2\%20Amaral.pdf

Asfaw, A. Does supermarket purchase affect the dietary practices of households? Some empirical evidence from Guatemala. Development Policy Review, 26(2), 227-243, 2008. doi: 10.1111/j.1467-7679.2008.00407.x

Bridging the Divide. Ferramentas. 2013. Available at: https://projects.ncsu.edu/project/amazonia/brazil_proj/ ferramentas.html

Garson, G. D. Cluster analysis. Asheboro, NC: Statistical Associates Publishers, 2012.

IBGE - Brazilian Institute of Geography and Statistics. Socio-demographic Census, 2010, 2012. Available at: http:// www.ibge.gov.br/english/presidencia/noticias/noticia_visualiza.php?id_noticia $=1866$

Johns, T.; Sthapit, B. R. Biocultural diversity in the sustainability of developing country good systems. Food Nutrition 
Bulletin, 25(2), 143-155, 2004.

Mooi, E.; Sarstedt, M. Cluster analysis. In: Mooi, E.; Sarstedt, M. A concise guide to market research: The process, data, and methods using IBM SPSS statistics. Springerverlag Berlin Heidelberg. 2011, p. 240-265.

Popkin, B. M. The nutrition transition: an overview of world patterns of change. Nutrition reviews, 62(2), 140143, 2004. Available at: https://www.ncbi.nlm.nih.gov/ pubmed/15387480

Rossiter, J. R.; Percy, L. Advertising and Promotion Management, McGraw-Hill, New York, 1987.

Shackleton, S.; Shanley, P.; Ndoye, O. Invisible but viable: Recognizing local markets for non-timber forest products. International Forestry Review, 9(3), 697-712, 2007. doi: 10.1505/ifor.9.3.697

Shanley, P.; Cymerys, M.; Serra, M.; Medina, G. Fruit trees and useful plants in Amazonian life, FAO, CIFOR and PPI (English edition), 2011.

Shanley, P.; Luz, L. The impacts of forest degradation on medicinal plant use and implications for health care in eastern Amazonia. Bioscience, 53(6), 573-584, 2003. doi: 10.1641/0006-3568(2003)053[0573:TIOFDO]2.0.CO;2

SPSS. The SPSS TwoStep cluster component, 2001. (Technical report). Available at: http://www.spss.ch/ upload/1122644952_The\%20SPSS\%20TwoStep\%20Cluster\%20Component.pdf

Ticktin, T. The ecological implications of harvesting nontimber forest products. Journal of Applied Ecology, 41(1), 11-21, 2004. 